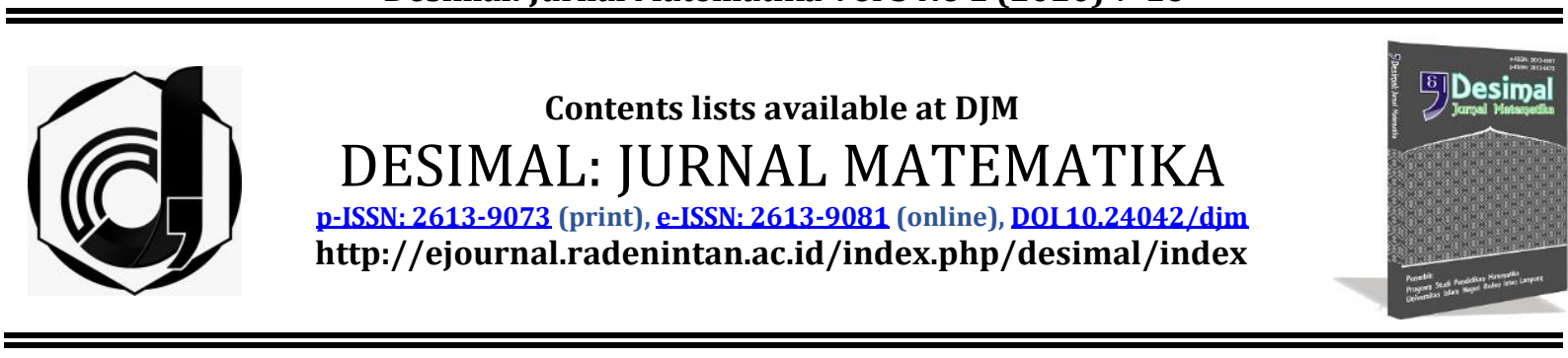

\title{
Learning Models to Improved Mathematical Communication Skills
}

Burhan Eko Purwanto ${ }^{1,}$, Icha Jusmalisa ${ }^{2}$, Indah Permata Sari², Agus Jatmiko², Andika Eko Pasetiyo $^{3}$

1 Universitas Pancasakti Tegal, Indonesia

2 Universitas Islam Negeri Raden Intan Lampung, Indonesia

3 University of Melbourne, Australia

\section{ARTICLE INFO}

\begin{tabular}{ll}
\multicolumn{2}{l}{ Article History } \\
Received & $: 09-09-2019$ \\
Revised & $: 10-10-2019$ \\
Accepted & $: 07-01-2020$ \\
Published & $: 26-01-2020$
\end{tabular}

Keywords:

Auditory, Intellectually, Repetition

(AIR);

Cooperative Think Pair Share (TPS)

type;

mathematical communication skills.

*Correspondence: E-mail:

burhan.ekopurwanto@gmail.com

Doi:

$\underline{10.24042 / d j m . v 3 i 1.5650}$

\begin{abstract}
The problem faced by students in slow learning is in terms of communication. The use of Auditory, Intellectually, Repetition (AIR) and Cooperative Think Pair Share (TPS) types is needed to help students communicate mathematically in expressing mathematical ideas. This study aims to determine whether or not there are differences in mathematical communication skills of students using the Auditory, Intellectually, Repetition (AIR) learning model with students who use Think Pair Share (TPS) Cooperative learning models. This research uses a quantitative approach using the Quasi Experiment method. The research design is in the form of posttest only, non-equivalent group design. Testing data using the T test with Independent Samples T-Test. Based on the results of hypothesis testing obtained pvalue $>\alpha 0.05$. So it was concluded that there were indications of differences between Auditory, Intellectually, Repetition (AIR) learning models with (TPS) Cooperative learning models and superior (AIR) learning models compared to Cooperative learning models of (TPS) Type in influencing students' mathematical communication skills.
\end{abstract}

\section{INTRODUCTION}

Mathematical communication skills are one of the abilities students must have (Aminah, Wijaya, \& Yuspriyati, 2018). One aspect that needs to be taught to students is how they are able to express their thoughts both in writing and in words, so that they are able to interact with the community (Hodiyanto, 2017). There have been several previous studies regarding mathematical communication skills (Lusiawati, 2013; Wulandari, 2016).

\section{Mathematical} communication skills are very important because with mathematical communication, students can communicate mathematical ideas with 
symbols, tables, graphs, or diagrams (Dharma, Pujiastuti, \& Harianja, 2019; Junaedi, 2010; Ningrum, 2016; Nuraeni \& Luritawaty, 2016; Prihastuti \& Riyadi, 2014; Purwati, Sessu, \& Jursa, 2018; Sakti, Rahardjo, \& As'ari, 2017; N. Wahyuni, Mirza, \& BS, 2018). One way to further develop mathematical communication skills is to apply an appropriate learning model.

There are various kinds of learning models that are considered to be able to influence mathematical communication skills, one of which is the Auditory Intellectually Repetition (AIR) learning method, (listening) (S. Huda, Anggraini, et al., 2019), Intellectually (thinking), and Repetition (repetition). Based on previous research, there have been studies that discuss AIR learning models for students' reasoning abilities (Rahmawati, Lestari, \& Umam, 2019), mathematics learning achievement (Habibi et al., 2019), speaking skills, mathematical problem solving abilities(S. Huda, Sholikhakh, et al., 2019), student understanding(Prastowo et al., 2019), activeness and learning achievement (Agustiana, Putra, \& Farida, 2018; Ainia, Kurniasih, \& Sapti, 2012; I.M, 2014; Linuwih \& Sukwati, 2014; Mustika \& Kinanti, 2018; Purnamasari, 2014; Puspitawedana, Sujadi, \& Harini, 2014; Sulistyaningsih \& Istiqomah, 2014; Widiastuti, Suniasih, \& Kristiantari, 2014).

Another learning model that is using cooperative type Think Pair Share. In this method there are three stages, namely Thinking, Pairing and Sharing (Ayukmartina, Sudjadi, \& Purnami, 2014; Isari, Sanusi, \& Krisdiana, 2014; Sugiharti,
2013; R. S. Wahyuni \& Harini, 2017). The Think Pair Share (TPS) method is a type of cooperative learning that is designed to influence learners' interaction patterns and provide an opportunity for each student to show their participation to others (Hanadayani \& Sujadi, 2014). Think Pair Share is also one model of learning with small groups (Kasimuddin, 2016). The number of group members consisting of only 2 people (in pairs) can optimize the active role of each student in the group and make it easier for students to cooperate with each other in expressing and discussing mathematical ideas they have both in oral and written form (Susanti, 2014; Wijayanto, 2015). This learning method prioritizes student learning activities together in groups so as to develop social relationships in problem solving learning (Wulan Sari, Kusmanto, \& Sujadi, 2014). So the purpose of the writer to make this article is to compare the two learning models of Auditory Intellectually Repetition (AIR) and cooperative Think Think Share (TPS) types whether there are differences in the two models and the more superior between the two(S. Huda, Tsani, Syazali, Umam, \& Jermsittiparsert, 2020).

\section{METHOD}

This type of research is quantitative research. The research method used in this study is experimental research (experimental research). The research design used in quasiexperimental (quasi-experimental design) with the research design is posttest only, non-equivalent group design. 
Desimal, 3 (1), 2020 - 8

Burhan Eko Purwanto, Icha Jusmalisa, Indah Permata Sari, Agus Jatmiko, Andika Eko Pasetiyo

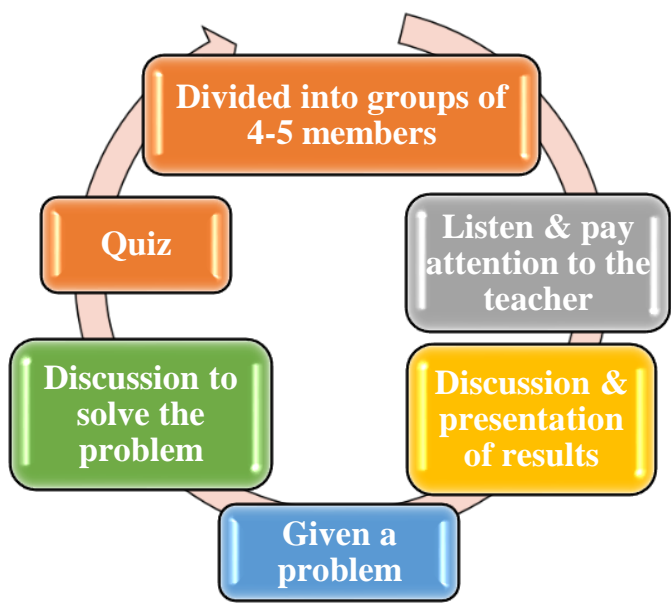

AIR

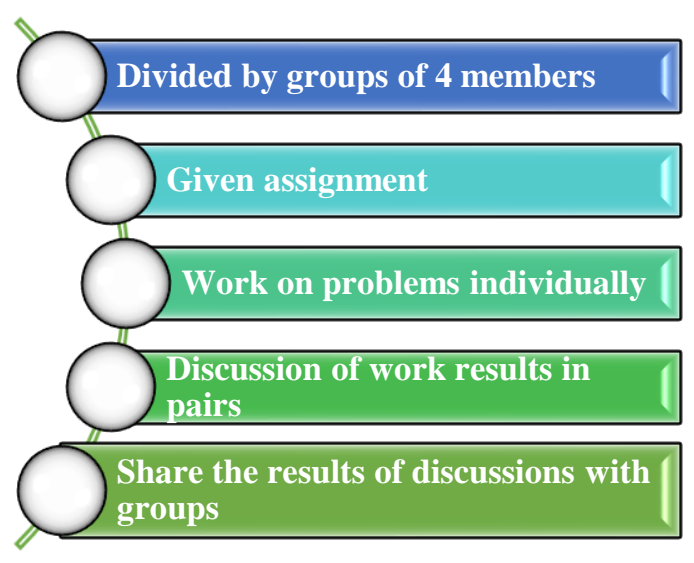

VS TPS

Figure 1. AIR and TPS Research Design Plans

Figure 1 illustrates the design of a research design which will compare the effects of the AIR and TPS learning models in influencing mathematical communication skills. In the AIR research design design the first thing to do is divide students into groups of 4-5 students, then students listen and pay attention to the teacher explain the material, then each group discusses the material they have learned and write the results to be presented in front of the class (auditory), after that the teacher gives the questions, then students are asked to discuss again to solve the problem (intellectually). After finishing the discussion, students get repetition of the material by quizzes to individually (repetition) (Khadijah \& Sukmawati, 2013).

For the design of the first TPS research design students were divided into groups of 4 members, then the teacher gave assignments to each group, each group member was told to do the task individually first (Think), then each group divided its members into pairs and then each pair discussed the results of their individual work (Pair), the two couples then meet again in their respective groups to share the results of the discussion (Share) (M. Huda, 2015).
The hypothesis test is carried out using the $\mathrm{T}$ test with the following problem formulation with significance level $\alpha$ 5\%:

$\mathrm{H}_{0}$ : Students 'mathematical communication using the Auditory, Intellectually, Repetition (AIR) learning model is the same as students' mathematical communication using the Think Pair Share (TPS) Cooperative learning model.

$\mathrm{H}_{\mathrm{a}}$ : Mathematical communication of students using the Auditory learning model, Intellectually, Repetition (AIR) there is a difference with the mathematical communication of students by using the Cooperative learning model Type Think Pair Share (TPS). 
Desimal, 3 (1), 2020 - 9

Burhan Eko Purwanto, Icha Jusmalisa, Indah Permata Sari, Agus Jatmiko, Andika Eko Pasetiyo

\section{RESULTS AND DISCUSSION}

Based on the results of the posttest conducted in this study, the data obtained were then analyzed using the centralization rules shown in Table 1.

Table 1. Data Mathematical Communication Skills

\begin{tabular}{|c|c|c|c|c|c|c|c|}
\hline Model & $\mathbf{N}$ & Range & Minimum & Maximum & Mean & $\begin{array}{c}\text { Std. } \\
\text { Deviation }\end{array}$ & Variance \\
\hline AIR & 30 & 29.00 & 71.00 & 100.00 & 81.6333 & 8.19791 & 67.206 \\
\hline TPS & 23 & 41.67 & 50.00 & 91.67 & 70.21 & 11.17787 & 124.945 \\
\hline
\end{tabular}

Based on Table 1 for mathematical communication skills data using two types of learning models, namely the AIR model and the TPS model, the number of members or respondents in each group are 30 and 23 members with a mean number of 81.6333 and 70.21. From these data also obtained Std. Deviation for the AIR model of 8,19791 and the TPS model of 11,17787, from the results of the research above, there was a significant difference in the mean value and also the Std.Deviation of each learning model. The smaller the standard deviation indicates that the data does not spread and the better the data shows. It can be concluded that the AIR learning model is better than the TPS learning model.

To strengthen the results of the above research, a $\mathrm{T}$ test was then performed using the Independent Samples T-Test. The recapitulation results of the T test results in Table 2 .

Table 2. Independent Samples Test

\begin{tabular}{|c|c|c|c|c|c|c|c|}
\hline & & \multicolumn{2}{|c|}{$\begin{array}{l}\text { Levene's Test } \\
\text { for Equality of } \\
\text { Variances }\end{array}$} & \multicolumn{4}{|c|}{ T-Test for Equality of Mean } \\
\hline & & $\mathbf{F}$ & Sig. & $\mathbf{t}$ & df & $\begin{array}{c}\text { p- } \\
\text { value }\end{array}$ & $\begin{array}{c}\text { Mean } \\
\text { Differences }\end{array}$ \\
\hline $\begin{array}{c}\text { Learning } \\
\text { Model }\end{array}$ & $\begin{array}{l}\text { Equal } \\
\text { variances } \\
\text { assumed } \\
\text { Equal } \\
\text { variances } \\
\text { not } \\
\text { assumed }\end{array}$ & 1.594 & 0.213 & 4.295 & 38.871 & 0.000 & 11.42333 \\
\hline
\end{tabular}

Meanwhile, for Table 2 based on the same data for the $\mathrm{T}$ Test using the Independent Samples Test with IBM SPSS on the AIR learning model and the TPS learning model as a sample, the output results obtained are in the Levene's Test of Equality of Variances $F$ value of 1.594 and sig. or significance of 0.213 . Because the significance value of $0.213>$ significance level $\alpha 0.05$ indicates that the data variance is assumed to be the same. Because the variance test obtained the same data, the p-value in the T-Test for Equality Mean column used is in the first row Equal variances assumed with a p-value of 0,000 . The results obtained $p$-value of $0,000<\alpha 0.05$ then $\mathrm{HO}$ is rejected. So it was concluded that at a significance level of $\alpha$ of $5 \%$ learning models using the AIR model and the TPS model on mathematical communication there were differences. Seen in Table 1 on the Mean line that the AIR learning model and the TPS learning model have different Mean with the average difference in the Mean Differences column in the Independent Sample Test table of 11.42333 which 
statistically assumes that the AIR learning model and the TPS learning model have differences and the AIR learning model is more superior than the TPS learning model.

This happens because the Auditory learning model, Intellectually, Repetition (AIR) contains several steps in its implementation that are superior to Cooperative Think Pair Share (TPS) types, where the teacher explains the discussion material first before then being analyzed by students, after which group representatives are required to dare to present the results of group discussions in front of the class. In addition to being given questions to be solved together with the group students individually get repetition of material by being given a quiz at the final stage after the discussion is over.

Next to strengthen the conclusions, researchers review from each stage of the learning model that researchers use. In the first stage all learning models do the preparation including preparing a discussion group, the TPS model after students are divided into their groups and then divided again in pairs. Then in the second stage in the TPS learning model the teacher directly gives questions to the students, then the questions are first done individually to train students' thinking power, then in the third stage the work results of each student are discussed in pairs. At the last stage students rejoin their groups to discuss in groups.

The stages of preparation in the AIR learning model after group formation, the second stage is the teacher explaining to students the material to be used for discussion. Furthermore, in the third stage students are asked to listen and pay attention and understand the material conveyed by the teacher. The fourth stage, each group is welcome to conduct discussions. The results of the discussion are then written to be presented in front of the class. Then, at the fifth and sixth stages each group is given questions by the teacher which is then discussed again in groups to solve the problem. The last stage is, the teacher gives a repetition of material in the form of a quiz. The teacher gives quizzes to students which are then done individually. The purpose of this repetition is that students repeat or review the discussion material earlier and also become one of the differentiators from other learning models (Purnomo, 2018).

Strengthened by the results of previous studies, that the TPS learning model can also improve mathematical communication skills and confidence, learning achievement, mathematics learning activities and results, learning motivation (Ayukmartina, Fibriana, 2014; Dharma,I.D.P.P, 2019; Isari, Sri, 2014; Kasimuddin, Drs.H., 2016; Lusiawati, Eni, 2013; Sugiharti, Eka Handayani, 2013; Wahyuni, RR Sri, and Esti Harini, 2017; Wulandari, Wulan Sri, 2016; Wulan Sari, Arin Dwi, 2014). Likewise the AIR model has an impact on mathematical communication skills. This is in line with the results of previous studies which stated the AIR learning model also impacts and influences and enhances students' reasoning abilities, mathematics learning achievement, speaking skills, mathematical problem solving abilities, student understanding, activeness and learning achievement (Agustiana et al., 2018; Ainia et al., 2012; I.M, 2014; Linuwih \& Sukwati, 2014; Mustika \& Kinanti, 2018; Purnamasari, 2014; Puspitawedana et al., 2014; Sulistyaningsih \& Istiqomah, 2014; Widiastuti et al., 2014).

TPS learning model can also improve mathematical communication skills and confidence, learning achievement, activities and learning outcomes in mathematics, learning motivation (Ayukmartina, Fibriana, 
2014; Dharma,I.D.P.P, 2019; Isari, Sri, 2014; Kasimuddin, Drs.H., 2016; Lusiawati, Eni, 2013; Sugiharti, Eka Handayani, 2013; Wahyuni, RR Sri, and Esti Harini, 2017; Wulandari, Wulan Sri, 2016; Wulan Sari, Arin Dwi, 2014). However, the results of the study of the authors of the two models turned out to have significant differences, the Auditory Intellectually Repetition (AIR) learning model was superior to the Think Pair Share (TPS) cooperative type because of the different steps in implementing the two methods (M. Huda, 2015; Khadijah \& Sukmawati, 2013). The AIR learning model has a greater impact on mathematical communication skills compared to the TPS learning model.

\section{CONCLUSIONS AND SUGGESTIONS}

Based on the results of data analysis and discussion, it is found that there is a difference between the influence of students' mathematical communication using the Auditory, Intellectually, Repetition (AIR) learning model using the Cooperative learning model Type Think Pair Share (TPS). The results of hypothesis testing using IBM SPSS with the $\mathrm{T}$ test through the Independent Sample Test test obtained a $p$-value of 0,000 . Because the $p$-value is $0,000<\alpha 0.05$ so based on the decision making criteria in the hypothesis test it can be concluded that $\mathrm{HO}$ is rejected. With this mathematical communication, students use the Auditory learning model, Intellectually, Repetition (AIR), there is a difference with the mathematical communication of students using the Think Pair Share (TPS) Cooperative learning model. From the results of the discussion it can also be seen that students' mathematical communication using Auditory, Intellectually, Repetition (AIR) is better than those using Think Pair Share Type Cooperative learning models (TPS) with a difference in the amount of 11.42333.
The advice that researchers can give based on the results of these studies, teachers should be more creative and innovative in using and developing a learning model. The more learning models, then we can analyze which learning models have more impact to improve students' mathematical communication skills, one of which is the Auditory, Intellectually, Repetition (AIR) learning model.

\section{REFERENCES}

Agustiana, E., Putra, F. G., \& Farida. (2018). Pengaruh Auditory, Intellectually, Repetition ( AIR) dengan Pendekatan Lesson Study terhadap Kemampuan Pemecahan Masalah Matematis. Desimal, 1(1), 1-6.

Ainia, Q., Kurniasih, N., \& Sapti, M. (2012). Eksperimentasi Model Pembelajaran Auditory Intellectually Repetition ( Air ) Terhadap Prestasi Belajar Matematika Ditinjau Dari Karakter Belajar Siswa Kelas Vii Smp Negeri Se-Kecamatan Kaligesing Tahun 2011/2012. (November), MP710MP716.

Aminah, S., Wijaya, T. T., \& Yuspriyati, D. (2018). Analisis Kemampuan Komunikasi Matematis Siswa Kelas Viii Pada Materi Himpunan. Jurnal Cendekia: Jurnal Pendidikan Matematika, 1(1), 15-22. https://doi.org/10.31004/cendekia .v2i1.29

Arzak, \& Ibrahim, M. (2017). Efektivitas Model Pembelajaran Kooperatif Tipe Two Stay Two Stray (Tsts) Terhadap Hasil Belajar Matematika Siswa Kelas Viii Smp Negeri 10 Kendari Pada Pokok Bahasan Operasi Bentuk Aljabar. Jurnal Penelitian Pendidikan Matematika, 3(1), 31-44.

Ayukmartina, F., Sudjadi, A. A., \& Purnami, A. S. (2014). Matematika 
Desimal, 3 (1), 2020 - 12

Burhan Eko Purwanto, Icha Jusmalisa, Indah Permata Sari, Agus Jatmiko, Andika Eko Pasetiyo

Melalui Model Pembelajaran Think Pair Share Siswa Kelas Viid Smp N 1 Srumbung Kabupaten Magelang. UNION: Jurnal Pendidikan Matematika, 2(1), 97-102.

Dharma, I. D. P. P. ., Pujiastuti, E., \& Harianja, M. (2019). Penerapan Model Pembelajaran TPS (ThinkPair-Share) untuk Meningkatkan Kemampuan Komunikasi Matematis dan Percaya Diri Peserta Didik Kelas X MIPA 1 SMA Negeri 6 Semarang Pada Materi Sistem Persamaan. PRISMA, Prosiding Seminar Nasional Matematika, 2, 239-246.

Habibi, B., Hartinah, S., Umam, R., Syazali, M., Lestari, F., Abdurrahman, A., \& Jauhariyah, D. (2019). Factor Determinants of Teacher Professionalism as Development of Student Learning Education at School of SMK PGRI in Tegal City, Indonesia. Journal of Gifted Education and Creativity, 6(2), 125134.

Hanadayani, P., \& Sujadi, A. A. (2014). Matematika Melalui Model Pembelajaran Numbered Heads Together Siswa Kelas VIII A SMP N 1 Pleret Bantul. UNION: Jurnal Pendidikan Matematika, 2(2), 127134.

Haruminati, N. W. Y., Suarni, N. K., \& Sudarma, I. K. (2016). Pengaruh Model Pembelajaran Savi Terhadap Minat Belajar Matematika Siswa Kelas IV SD Mutiara Singaraja. Mimbar Pgsd, IV(1), 1-11.

Hodiyanto, H. (2017). Kemampuan Komunikasi Matematis Dalam Pembelajaran Matematika. AdMathEdu, 7(1), 9-18.

Huda, M. (2015). Cooperative Learning (Metode, Teknik, Struktur dan Model Peneraoan). Yogyakarta: Pustaka Pelajar.
Huda, S., Anggraini, L., Saputri, R., Syazali, M., Umam, R., Islam, U., \& Radenintan, N. (2019). Learning Model to Improve The Ability to Understand Mathematical Concepts. PRISMA, 8(2), 173-181.

Huda, S., Sholikhakh, R. A., Bina, N. S., Lestari, F., Habibi, B., \& Suharso, P. (2019). Effect of Application Smart Circuit Learning Media to Mathematics Learning Outcomes : A Case Study of Islamic School Students. Journal for the Education of Gifted Young Scientists, 7(September), 699-715. https://doi.org/https://doi.org/10. 17478/jegys.597053

Huda, S., Tsani, I., Syazali, M., Umam, R., \& Jermsittiparsert, K. (2020). The management of educational system using three law Auguste Comte: A case of Islamic schools. Management Science Letters, 10(3). https://doi.org/10.5267/j.msl.2019 9.018

I.M, H. (2014). Keefektifan Auditory Intellectually

Repetition Berbantuan LKPD terhadap Kemampuan Penalaran Peserta Didik SMP. Kreano: Jurnal Matematika Kreatif-Inovatif, 5(1), 19.

https://doi.org/10.15294/kreano.v $5 i 1.3271$

Isari, S., Sanusi, S., \& Krisdiana, I. (2014). Efektivitas Metode Pembelajaran Think Pair Share (Tps) Dengan Metode Pembelajaran Guided Note Taking (Catatan Terbimbing) Terhadap Prestasi Belajar Matematika Pokok Bahasan Garis Dan Sudut Siswa Kelas Vii Mts Negeri Kota Madiun Tahun Ajaran 2013/2014. JIPM (Jurnal Ilmiah Pendidikan Matematika), 3(1). https://doi.org/10.25273/jipm.v3i 1.504 
Burhan Eko Purwanto, Icha Jusmalisa, Indah Permata Sari, Agus Jatmiko, Andika Eko Pasetiyo

Junaedi, I. (2010). Pembelajaran Matematika Dengan Strategi Writing In Perfomance Tasks (Wipt) Untuk Meningkatkan Kemampuan Menulis Matematis. Kreano: Jurnal Matematika Kreatif-Inovatif, 1(1), 11-20.

https://doi.org/10.15294/kreano.v $1 \mathrm{i} 1.218$

Kasimuddin, D. H. (2016). Penggunaan Model Pembelajaran Kooperatif Tipe Think Pair Share (TPS) Untuk Meningkatkan Aktivitas Dan Hasil Belajar Fisika Peserta Didik Kelas XI IPA 2 SMA Negeri 9 Makassar. Jurnal Pendidikan Fisika Universitas Muhammadiyah Makassar, 04(01), 54-72.

Khadijah, S., \& Sukmawati, A. R. (2013). Efektivitas model pembelajaran Auditory Intellectually Repetition dalam pengajaran matematika di kelas VII MTs. EDU-MAT Jurnal Pendidikan Matematika, 1(1), 6875.

Linuwih, S., \& Sukwati, N. O. E. (2014). Efektivitas Model Pembelajaran Auditory Intellectually Repetition ( Air ) Terhadap Pemahaman Siswa Pada Konsep Energi Dalam the Effectiveness of Auditory Intellectually Repetition ( Air ) Learning Model on Students'. Jurnal Pendidikan Fisika Indonesia, 10(2), 158-162. https://doi.org/10.15294/jpfi.v10i 2.3352

Lusiawati, E. (2013). Pengaruh Penerapan Model Pembelajaran Kooperatif Tipe Think -Pair-Share (TPS) Terhadap Kemampuan Komunikasi Matematis Siwa SMA. In Tesis. Jakarta: Universitas Terbuka.

Mustika, H., \& Kinanti, N. (2018). Pengaruh Penerapan Model Pembelajaran Auditory Intellectually Repetition (Air)
Terhadap Kemampuan Komunikasi Matematika Siswa Di Kelas Viii Smp Negeri 1 Pasir Penyu. MES: Journal of Mathematics Education and Science, 3(2), 153-158. https://doi.org/10.30743/mes.v3i2 .495

Ningrum, R. K. (2016). Meningkatkan Kemampuan Komunikasi Matematis Siswa Menggunakan Problem Based Learning berbasis Flexible Mathematical Thinking. Seminar Nasional Matematika X Universitas Negeri Semarang, 213-222.

Nuraeni, R., \& Luritawaty, I. P. (2016). Mengembangkan Kemampuan Komunikasi Matematik Siswa melalui Strategi Think Talk Write. Mosharafa: Jurnal Pendidikan Matematika, 5(2), 101-112. https://doi.org/10.31980/moshara fa.v5i2.265

Prastowo, R., Huda, S., Umam, R., Jermsittiparsert, K., Prasetiyo, A. E., Tortop, H. S., \& Syazali, M. (2019). The Effectiveness Of Environmental Geophysical Learning In Developing Academic Achievement And Conceptual Understanding of Electrodynamics: Applications Geoelectric Using Cooperative Learning Model. Jurnal Ilmiah Pendidikan Fisika Al-Biruni, 8(2), 165-175. https://doi.org/10.24042/jipfalbir uni.v0i0.4614

Prihastuti, L., \& Riyadi, A. (2014). Upaya Meningkatkan Kemampuan Komunikasi Matematika. Jurnal Derivat, 1(1), 29-34.

Purnamasari, Y. I. (2014). Pengaruh Model Pembelajaran Auditory Intellectually Repetition (Air) Terhadap Prestasi Belajar Matematika Pada Materi Aljabar Kelas Vii Smp Muhammadiyah 3 Jetis Tahun Pelajaran 2013/2014. 
Desimal, 3 (1), 2020 - 14

Burhan Eko Purwanto, Icha Jusmalisa, Indah Permata Sari, Agus Jatmiko, Andika Eko Pasetiyo

Purnomo, B. (2018). Pemahaman Konsep Matematika Siswa Melalui Model Pembelajaran Air (Auditory, Intellectualy, Repetition) Dan Model Pembelajaran Course Review Horay Sma Budi Utomo Jombang. Soulmath, VI(1), 1-14. https://doi.org/10.25139/sm.v6i1. 376

Purwati, D., Sessu, A., \& Jursa, H. (2018). Pengaruh Model Pembelajaran Auditory, Intellectually, Repetition (Air) Terhadap Peningkatan Pemecahan Masalah Matematis Siswa. 1, 240-249. https://doi.org/10.35194/jp.v6i2.5 8

Puspitawedana, D., Sujadi, A. A., \& Harini, E. (2014). Upaya Meningkatkan Kreativitas Dan Prestasi Belajar Matematika Melalui Model Pembelajaran Auditory Intellectually Repetition Siswa Kelas XD SMA Negeri 1 Tanjungsari Gunung Kidul Tahun Ajaran 2012/2013. UNION: Jurnal Pendidikan Matematika, 2(1), 8996.

Rahmawati, R., Lestari, F., \& Umam, R. (2019). Analysis of the Effectiveness of Learning in the Use of Learning Modules Against Student Learning Outcomes. Desimal: Jurnal Matematika, 2(3), 233-240.

Sakti, R. K., Rahardjo, S., \& As'ari, A. R. (2017). Komunikasi Matematis Siswa Dalam Menyelesaikan Masalah Persamaan dan Pertidaksamaan Linear Satu Variabel. 1(1), 419-423.

Sugiharti, E. H. (2013). Efektivitas Think Pair Share Terhadap Hasil Belajar Matematika Ditinjau Dari Kemampuan Awal. Prosiding Seminar Nasional Etnomatnesia, 505-510.

Sulistyaningsih, R., \& Istiqomah, I. (2014). Belajar Matematika Dengan
Model Pembelajaran Kooperatif Tipe Auditory Intellectually Repetition ( Air ) Siswa Kelas Viii C Smp Negeri 2 Jetis Bantul. UNION: Jurnal Pendidikan Matematika, 2(2), 221-230.

Susanti, V. D. (2014). Efektivitas Model Pembelajaran Portofolio Dan Model Pembelajaran Kooperatif Think Pair And Share (Tps) Terhadap Prestasi Belajar Matematika Ditinjau Dari Kreativitas Siswa Vii Smp Negeri 2 Kebonsari Tahun Ajaran 2011/2012. JIPM (Jurnal Ilmiah Pendidikan Matematika), 2(2), 32. https://doi.org/10.25273/jipm.v2i 2.476

Wahyuni, N., Mirza, A., \& BS, D. ahmad. (2018). Pengaruh model kooperatif tipe think-pair-share terhadap kemampuan komunikasi matematis siswa mts . Al-madani pontianak. 18.

Wahyuni, R. S., \& Harini, E. (2017). Pengaruh Pembelajaran Kooperatif Tipe Think Pair Share (Tps) Terhadap Prestasi Belajar Matematika Ditinjau Dari Motivasi Siswa Kelas X Sma Negeri 1 Pengasih Kulon Progo Tahun Pelajaran 2013/2014. UNION: Jurnal Ilmiah Pendidikan Matematika, 2(3), 249256.

https://doi.org/10.30738/.v2i3.20 8

Widiastuti, A. A. P. Y., Suniasih, N. W., \& Kristiantari, M. G. R. (2014). Pengaruh Model Auditory Intellectualy Repetition Berbantuan Tape Recorder Terhadap Keterampilan Berbicara. Jurnal Mimbar PGSD Universitas Pendidikan Ganesha, 2(1), 1-10.

Wijayanto, Z. (2015). Eksperimentasi Model Pembelajaran Kooperatif Tipe Think Pair Share (Tps) Dengan Pendekatan Open-Ended Ditinjau 
Desimal, 3 (1), 2020 - 15

Burhan Eko Purwanto, Icha Jusmalisa, Indah Permata Sari, Agus Jatmiko, Andika Eko Pasetiyo

Dari Disposisi Matematis Siswa Kelas Viii Smp Negeri Di Kabupaten Purworejo. Jurnal Ilmiah Pendidikan Matematika, 3(2), 427-4387.

Wulan Sari, A. D., Kusmanto, B., \& Sujadi, A. . (2014). Upaya peningkatan keaktifan dan prestasi belajar matematika dengan metode pembelajaran kooperatif tipe think pair share (tps) siswa kelas vii mts. Yp. Nurul huda tanah abang palembang. UNION: Jurnal Pendidikan Matematika, 2(1), 9-14. https://doi.org/10.1017/CB09781 107415324.004

Wulandari, W. S. (2016). Meningkatkan Kemampuan Komunikasi dan Motivasi Belajar Matematika Siswa Sekolah Dasar Melalui Pembelajaran Kooperatif Tipe Think Pair Share. Jurnal Universitas Pendidikan Indonesia. 
Desimal, 3 (1), 2020 - 16

Burhan Eko Purwanto, Icha Jusmalisa, Indah Permata Sari, Agus Jatmiko, Andika Eko Pasetiyo 